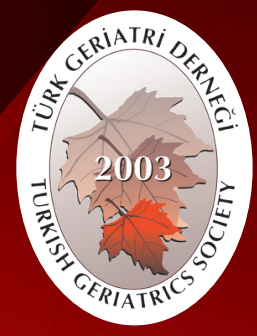

Turkish Journal of Geriatrics

DOI: 10.31086/tjgeri.2019150581

2019;22 (1):117-120

- Mehtap ÖZDEMIR ${ }^{1}$ (D)

- Yonca YANLI ${ }^{1}$ iD

\title{
GLOBAL AGEING IS A GROWING PROBLEM FOR ANAESTHESIOLOGISTS: A CASE OF REGIONAL BLOCKS IN A GERIATRIC PATIENT
}

\section{Abstract}

The geriatric patients who needs to emergency surgery increases depending on the ageing world population. These patients frequently have multiple comorbidities such as cardiac disease, diabetes mellitus, chronic obstructive pulmonary disease. Perioperative careful anesthesia management reduce risk factors, morbidities and mortality. Peripheral nerve blocks are preferred in geriatric patients, to protect the state of consciousness, creating minimal changes in hemodynamic and respiratory parameters and postoperative sufficient pain control. Regional anaesthesia supress surgical stress response. In this case report, we aimed to present an infraclavicular block and spinal anaesthesia combination in a 73 years old, American Society of Anesthesiologists Classification (ASA) IV geriatric patient who underwent emergency orthopaedic surgery due to trauma.

Keywords: Ageing; Anesthesia; Spinal; Emergencies; Geriatrics

CORRESPONDANCE

Mehtap ÖZDEMiR

University of Health Sciences, Umraniye

Training and Research Hospital, Department of

Anesthesiology and Reanimation, İstanbul, Turkey

Phone: 02166321818

e-mail: mehtapoz@yahoo.com

Received: 20/03/2018

Accepted: $\quad 30 / 01 / 2019$

1 University of Health Sciences, Umraniye

Training and Research Hospital, Department of Anesthesiology and Reanimation, Istanbul, Turkey

\section{KÜRESEL YAŞLANMA, ANESTEZISTLER IÇiN BÜYÜYEN BİR PROBLEM: YAŞLI BİR HASTADA REJYONEL BLOKLAR}

$\ddot{\mathrm{O}}_{\mathrm{z}}$

Acil cerrahiye ihtiyaç duyan yaşlı hastalar dünya nüfusunun ihtiyarlamasına bağlı olarak artmaktadır. Bu hastalar çoğu kez kardiyak hastalıklar, diyabetes mellitus, kronik obstruktif akciğer hastalığı gibi birden fazla yandaş hastalığa sahip olmaktadırlar. Perioperatif dikkatli anestezi yönetimi risk faktörlerini, morbidite ve ölüm oranlarını azaltır. Periferik sinir blokları yaşı hastalarda, bilinç durumunu korumaları, hemodinamik ve solunumsal parametrelerde minimal değişiklik yapmaları ve operasyon sonrası yeterli ağrı kontrolü sağlamaları nedeniyle tercih edilirler. Rejyonel anestezi ise cerrahi stres cevabını baskılamaktadır. Bu olgu sunumunda travmaya bağlı acil ortopedi cerrahisi geçiren 73 yaşında, Amerikan Anestezi Derneği Klasifikasyonu IV yaşlı bir hastada infraklavikuler blok ve spinal anestezi kombinasyonunun sunulması amaçlanmıştır.

Anahtar sözcükler: Küresel yaşlanma; Spinal anestezi; Acil cerrahi; Yaşlı hastalar 


\section{INTRODUCTION}

The number of 'elderly' people ( $>65$ years) has increased by three times over the last 50 years and the most rapidly growing age group is that aged 80 years and older (1). As a result of better health care, nutrition, education, and general living standards, the ageing population has increased globally.

It is believed that more than half of the elderly population will require surgical intervention at least once in their remaining life. Steadily increasing numbers of geriatric patients require orthopaedic surgeries because of urgent traumas. In general, they become intolerant towards surgical stress due to decreased functional reserve of organ systems (2). The practise of anaesthesiology is more complex in these patients because of a greater number and difficulty of comorbid conditions.

Regional anaesthetic and analgesic techniques provide physiologic benefits intra-operatively and post-operatively (3). Furthermore these techniques may attenuate the pathophysiology that presents post-opertively.

Here we discuss our regional anaesthesia practices with an infraclavicular block and spinal anaesthesia combination in a geriatric patient who underwent surgery for a left femoral and left radial fracture simultaneously.

\section{CASE}

Our patient was a 73-years-old, 156-cm tall American Society of Anesthesiologists (ASA) class IV, female weighing $45 \mathrm{~kg}$. During pre-operative evaluation, she presented with atrial fibrillation, congestive heart failure, chronic lymphocytic leukaemia, diabetes mellitus, hypertension and a history of total thyroidectomy. On physical examination; the sounds of pulmonary auscultation were decreased bilaterally and the heartbeat was arrhythmic. Her medications included metoprolol succinate $25 \mathrm{mg}$, verapamil $120 \mathrm{mg}$, warfarin sodium 5mg, levothyroxine sodium 150mg, atorvastatin $10 \mathrm{mg}$ daily and metformin $500 \mathrm{mg}$ twice a daily.

Pre-operative laboratory results revealed the following: haemoglobin: $8.4 \mathrm{~g} / \mathrm{dl}$, haematocrit: $27.6 \%$, blood sugar: $154 \mathrm{mg} / \mathrm{dl}$, blood urea:38mg/ $\mathrm{dl}$, serum creatinine: $0.7 \mathrm{mg} / \mathrm{dl}$. Pre-operative serum electrolytes, platelet count, bleeding time, prothrombin time, activated partial thromboplastin time (aPTT) and international normalised ratio (INR) were normal. Cardiothoracic index was higher on her chest x-ray. Thorax computed tomography (CT) and CT angiography showed that her heart was larger than normal, there were pleural effusion signs in bilateral hemithorax, there was consolidation in the lower lobe and athelectatic changes in the middle right pulmonary lobe. Echocardiography revealed tricuspid insufficiency, pulmonary hypertension, mild mitral insufficiency and an ejection fraction of $50 \%$. Pre-operative blood gases were as follows: $\mathrm{pH}: 7.39, \quad \mathrm{pCO}_{2}: 35, \quad \mathrm{pO}_{2}: 43.5, \quad \mathrm{SpO}_{2}: 76.6, \quad$ Lac:22, $\mathrm{HCO}_{3}: 21.9$ (Table 1).

In the operating room standard monitoring (electrocardiogram, non-invasive blood pressure, peripheral oxygen saturation) was applied. Information about the procedure was explained to the patient and written consent was obtained.

Preoperatively, the patient's non-invasive blood pressure (NIBP) was 130/94 $\mathrm{mmHg}$, heart rate (HR):103/min, $\mathrm{SpO}_{2}: 90 \%$ under $2 \mathrm{ldk}^{-1}$ oxygen $\left(\mathrm{O}_{2}\right)$ through a face mask. We planned two surgeries simultaneously, in agreement with the two surgeons, to shorten her operation time. Infraclavicular block and spinal anaesthesia were administered. Initially an infraclavicular block was applied $2 \mathrm{~cm}$ medial and $2 \mathrm{~cm}$ inferior to the coracoid process of the scapula with a stimulation needle, via nerve stimulator. The stimulation current was started at $1 \mathrm{~mA}$, with a frequency of $2 \mathrm{~Hz}$ for $0.1 \mathrm{~ms}$ and finger and thumb flexion was found at $0.5 \mathrm{~mA}$. After localisation of the plexus brachialis, lidocaine $(2 \% ; 10 \mathrm{~mL})$ with levobupivacaine $(0.5 \% ; 20 \mathrm{~mL})$ was given. The sensation and motor blocks were adequate at $16^{\text {th }}$ min. 
Second, the patient was placed in the lateral decubitus position. Spinal anaesthesia was applied from the L3-L4 spinal space using a 26gauge atraumatic spinal needle with levobupivacaine $(0.5 \% ; 2.5 \mathrm{~mL})$. Five minutes later the Bromage anaesthesia score was 3 and the block level was at L1. The operation began $10 \mathrm{~min}$ later. Our patient was sleeping during the surgery without any sedation. Maximum block-level was T7. Two orthopaedic surgeons performed both procedures at the same time and the operation time was $135 \mathrm{~min}$. The patient underwent surgery without pain, stayed in the recovery room for $1 \mathrm{~h}$, and only needed analgesics 4 $\mathrm{h}$ post-operation in the ward (Table 2).

Table 1. Pre-operative and per-operative blood gas results.

\begin{tabular}{|l|r|r|r|r|r|r|}
\hline & $\mathrm{PH}$ & $\mathrm{PO}_{2}$ & $\mathrm{PCO}_{2}$ & $\mathrm{SPO}_{2}$ & Lac & BE \\
\hline Preoperative & 7.39 & 43.5 & 35 & 76.6 & 22 & -2.9 \\
\hline Peroperative & 7.39 & 154 & 34.5 & 99.9 & 6 & -3.4 \\
\hline
\end{tabular}

Table 2. NIBP (noninvasive blood pressure), HR (heart rate) and SpO2 (peripheral oxygen saturation) levels.

\begin{tabular}{|l|r|r|r|}
\hline & NIBP $(\mathbf{m m H g})$ & $\mathbf{H R}$ (beat/dk) & $\mathbf{S P O}_{2}(\%)$ \\
\hline Preoperative & $130 / 90$ & 103 & 90 \\
\hline After infraclavicular block (16.min) & $129 / 99$ & 83 & 93 \\
\hline After spinal anaesthesia (26.min) & $90 / 53$ & 112 & 96 \\
\hline Per-operative (60.min) & $102 / 66$ & 78 & 97 \\
\hline Post-operative (140.min) & $103 / 61$ & 90 & 99 \\
\hline
\end{tabular}

\section{DISCUSSION}

Ageing population steadily increases all around the world. These population require meticulous medical evaluation: their risk factors have to be well described and perioperative management and postoperative care have to be planned (4). Elderly patients who present to emergency services due to a trauma also have chronic diseases (such as cardiac disease, diabetes mellitus, chronic obstructive pulmonary disease). Ageing calcification in rib cartilage and degeneration of the ribcage also have been observed in such patients. The compliance of pulmonary tissue and decrease in functioning of respiratory muscle causes a reduction in total pulmonary volume (5). For this reason, respiratory problems are major complications in the early postoperative period. Additionally, cardiac morbidity is the most common cause of death after major surgical procedures (6). Peri-operative sympathetic activation has an important role in the development of myocardial ischaemia.

General and regional anesthetic techniques are widely used in clinical practice. These techniques affect early- and late-term morbidity and mortality in high risk geriatric patients. There are some studies show that regional anaesthetic techniques associated with fewer cerebrovasculer accidents, and reduced acute postoperative confusion in orthopedic surgery $(4,7,8)$. Also, regional anaesthesia reduce blood loss, improve 
peripheral vascular circulation, suppress surgical stress response and provide better post-operative pain control via blocking afferent and efferent signals to and from the spinal cord. Moreover, these techniques may reduce sympathetic activation and short-term mortality (6).

Different approaches exist to produce local anaesthetic blockade of the brachial plexus. In recent studies visualising brachial plexus using ultrasound have become very popular $(9,10)$. Whereas another study pointed out that the nerve localization with ultrasound or neurostimulation did not show any significant differences in anaesthetic efficacy. The infraclavicular block is a safe and simple technique regardless of whether ultrasound or neurostimulation guidance is used for providing surgical anaesthesia of the lower arm. Another advantage of this technique is reduced tourniquet pain during surgery (11). In emergency conditions, such as that in our case,

\section{REFERENCES}

1. White PF, White LM, Monk T et al. perioperative care for the older outpatient undergoing ambulatory surgery. Anesth Analg 2012 Jun;114(6):1190-215. (PMID:22467899).

1. JH Silverstein. The Practice of Geriatric Anesthesia. In: J. H. Silverstein, G. A. Rooke, J.G. Reves, C. H. McLeskey(Eds). Geriatric Anesthesiology 2nd edition, Springer, NY, USA 2008, pp 3-14.

2. Liu S, Carpenter RL, Neal JM. Epidural anesthesia and analgesia. Their role in postoperative outcome. Anesthesiology 1995;82:1474-506. (PMID:7793661).

3. Luger TJ, Kammerlander C, Luger MF, KammeranderKnauer U, Gosch M. Mode of Anesthesia, mortality and outcome in geriatric patients. Z Gerontol Geriat 2014;47:110-24. (PMID:24619042).

4. Cartin-Ceba R, Sprung J, Gajic O, Warner DO. The Aging Respiratory System: Anesthetic Strategies to Minimize Perioperative Pulmonary Complications. In: J. H. Silverstein, G. A. Rooke, J.G. Reves, C. H. McLeskey (Eds). Geriatric Anesthesiology 2nd edition, Springer, NY, USA 2008 pp 149-164.

5. B Veering. Management of Regional Anesthesia. In: J. H. Silverstein, G. A. Rooke, J.G. Reves, C. the infraclavicular block does not require upper limb abduction, and seems to be an interesting alternative to the axillary block.

Functional reserve and compensation ability for physiologic stress are mostly reduced in the geriatric population. This fact affects pre-operative assessment and peri-operative care of elderly patients. When considering major postoperative complications, such as respiratory problems, regional block combinations are the correct choice for geriatric patients with multiple systemic diseases. These techniques provide several beneficial effects in elderly patients with trauma. The choices of regional anaesthesia are important for proper operation and suitable patients, especially considering the increasing numbers of geriatric patients globally. Therefore we aimed to emphasise that regional techniques should be considered and performed more often in the elderly who have even two traumas at different regions at the same time.

H. McLeskey (Eds). Geriatric Anesthesiology 2nd edition, Springer, NY, USA 2008, pp 278-89.

6. LugerTJ, Kammerlander C, Gosch M, et al. Neuroaxial versus general anaesthesia in geriatric patients for hip fracture surgery: does it matter? Osteoporos Int 2010;21(Suppl 4):S555-72. (PMID:21057995).

7. Parker MJ, Handoll HHG, Griffiths R. Anaesthesia for hip fracture surgery in adults. Cochrane Database Syst Rev 2004;4:CD000521. (PMID:11687085).

8. Dingemans $E$, Williams $S R$, Arcand $G$ et al. Neurostimulation in ultrasoundguided infraclavicular block: a prospective randomized trial. Anesthesia and Analgesia 2007;104:1275-80. (PMID:17456686).

9. Sandhu NS, Manne JS, Medabalmi PK, Capan LM. Sonographically guided infraclavicular brachial plexus block in adults: a retrospective analysis of 1146 cases. Journal of Ultrasound in Medicine 2006;25:1555-61. (PMID:17121950).

10. Chin KJ, Alakkad $H$, Adhikary SD, Singh $M$. Infraclavicular brachial plexus block for regional anaesthesia of the lower arm. Cochrane Database Syst Rev 2013 aUG 28;(8):CD005487. (PMID:23986434). 